\title{
An emerging economy perspective on corporate sustainability reporting - main actors' views on the current state of affairs in Pakistan
}

\author{
Zeeshan Mahmood ${ }^{1}$ (D), Rehana Kouser ${ }^{1}$ and Md. Abdul Kaium Masud ${ }^{2,3^{*}}$
}

\author{
* Correspondence: masudbd08@ \\ gmail.com; masud@inha.edu \\ ${ }^{2}$ Department of Sustainability \\ Management, Inha University, \\ Incheon 22212, South Korea \\ ${ }^{3}$ Department of Business \\ Administration, Noakhali Science \\ and Technology University, Noakhali \\ 3814, Bangladesh \\ Full list of author information is \\ available at the end of the article
}

\begin{abstract}
The purpose of this paper is to explore the main actors' views on the current state of sustainability reporting in a developing country context. This qualitative study is based on the interviews of 20 individuals and organizations from Pakistan who were identified as main actors involved in the practice of sustainability reporting. This paper draws on the arguments of multiple theoretical frameworks, including legitimacy theory, stakeholders' theory, institutional theory, political cost theory, and signalling theory. Following a semi-structured interview protocol, main actors were asked to share their views on the drivers and barriers of sustainability reporting, sufficiency and suitability of sustainability-related regulation and standards, perceived benefits of sustainability reporting, level of stakeholder engagement and transparency. Interviews were then analysed to compare the viewpoints of different stakeholder groups on various issues. This paper concludes that, like other emerging and developing economies, the practice of sustainability reporting is largely driven by the external forces. Foreign buyers, international professional associations and standard-setting organizations are playing a pivotal role in the emergence and development of sustainability reporting. Sustainability reporting awards also played an important role as they provide the normative basis and intangible benefits for reporting. Despite these external forces driving the emergence and development of SR in Pakistan, the structural and cultural conditions that exist in the societal context of Pakistan significantly impact the disclosure practices and organizational rationales for SR. In particular, weak government structures, lack of awareness and interest in sustainability matters, lack of regulation, lack of enforcement capabilities, lack of a political will has been identified as the main barriers of SR. The paper explores the perceptions of both managerial and non-managerial stakeholders regarding the current state of sustainability reporting in Pakistan.
\end{abstract}

Keywords: Drivers and barriers, Sustainability reporting, GRI, CSR, Managerial and non-managerial perceptions, Emerging and developing economies, Pakistan

\section{Introduction}

The socio-economic and political realities of emerging and developing economies are different from those of the developed economies. According to the IMF (2012), emerging and developing economies are the most rapidly expanding, and hence the most

(c) The Author(s). 2019 Open Access This article is distributed under the terms of the Creative Commons Attribution 4.0 International License (http://creativecommons.org/licenses/by/4.0/), which permits unrestricted use, distribution, and reproduction in any medium, provided you give appropriate credit to the original author(s) and the source, provide a link to the Creative Commons license, and indicate if changes were made. 
lucrative growth markets for business. However, it is in these countries where the social and environmental crises are usually most acutely felt in the world (Yunis et al. 2018; Masud et al. 2018a, b; Mahmood et al. 2018; Eweje 2014; Visser 2008). In addition, these are the countries where globalization, economic growth, investment, and business activity are likely to have the most dramatic social and environmental impacts (Sanchez-Triana et al. 2014). Understandably, developing countries present a distinctive set of sustainability challenges which are collectively quite different to those faced in the developed world (Husted and de Sousa-Filho 2018; Belal et al. 2015; Crane et al. 2008). Since sustainability reporting has the potential to increase transparency and accountability of an organization towards sustainability, it is important to increase our understanding of why and how sustainability accounting and reporting is, or is not, evolving in emerging and developing economies (Belal et al. 2013; Correa and Larrinaga 2015).

Business organizations working in emerging and developing economies are likely to have a crucial role, both positive and negative, in sustainable development which amplifies the need for and importance of research within this context (Correa and Larrinaga 2015, p. 14). Also, there is more need for, and importance of, organizational transparency and accountability because of the vulnerability and exploitability that prevails in emerging and developing economies (Belal et al. 2013, 2015). Because of this, and since sustainability reporting is profoundly under-researched in developing countries, there is a tremendous opportunity for improving our knowledge and understanding and to contribute to the literature.

Accounting technologies (including reporting standards and guidelines) in developing countries are very often exported from the Western developed countries with pre-suppositional baggage that ignores the differences in the local context. Therefore, there is a need for research that highlights these differences in the context, as otherwise imported technologies may not contribute to sustainable development in developing countries (Belal and Owen 2007). Despite this, current research attention has largely been directed at approaches to sustainability reporting in developed rather than developing nations (Belal and Cooper 2011; Masud et al. 2018a, b; Bae et al. 2018).

Majority of the research in both developed and developing countries has tended to study sustainability reporting from a distance (Adams and Larrinaga-Gonzalez 2007). They fail to involve the actors that are directly or indirectly involved in the preparation of sustainability reports and the advancement of the field. The focus of previous research was on the analysis of external factors (such as stakeholder pressure, media coverage, critical events, country context) and was inclined to use quantitative methodologies (e.g. content analysis). In recent years researchers have highlighted the limited explanatory potential of such studies and calls for qualitative studies that should engage with actors and should study perception about important issues as well as internal processes of reporting (Belal and Owen 2015; Belal et al. 2015).

Considering the paucity of research in emerging and developing economies and lack of qualitative studies, this paper aims to conduct a broader field study of the main actors' views on different aspects of CSR in Pakistan. More specifically, this study conducts semi-structured interviews with 20 main actors including managers of reporting firms, regulators, consultants, NGOs, academics, professional accounting bodies and enablers of corporate sustainability reporting. The study addresses the question of 
managerial and stakeholders' perceptions about sustainability reporting practices, framework and guidelines in Pakistan. The study attempts to capture various drivers that are responsible for the uptake of SR initiatives in an emerging economy like; Pakistan.

\section{Theoretical development}

Prior studies have extensively used a different theoretical framework in the CSR disclosure. Based on the prior studies we developed a mixed theoretical framework in the study. The study deployed different socio-economic and socio-political theoretical discussion of CSR in the Pakistan context.

\section{Institutional theory}

Organisations exist in the institutional environment that deals with how social expectations are incorporated into the decisions making environment. The institutional theory defines different internal and external forces of the society and organisation along with rules and regulations which have been used for legitimacy seeking (Meyer and Rowan 1977; Comyns 2016). Institutional environment is incorporated with different organisational elements through the process of isomorphism. Institutional isomorphism is the combination of coercive, mimetic and normative pressure that ensures organisational commitment and strategy for societal expectations and organisations' growth (DiMaggio and Powell 1983). Different isomorphic formal and informal forces (e.g.; government, NGO, market competitions, standard and guidelines) obliged organisation to reduce legitimacy gap between society and stakeholder. CSR reporting is one kind of voluntary reporting that is the result of normative isomorphism. Therefore, the institutional environment considers inclusive actions in society to reduce information asymmetry. Prior literature vividly explored the influence of institutional pressures on CSR and sustainability. For example, Belal et al. 2017 explore the role of global regulative firms (big 4 audit firms) in driving SR in Bangladesh.

\section{Stakeholder theory}

Stakeholder theory defines the relationship of different stakeholders (e.g.; shareholders, customers, suppliers, creditors, civil society, media, and government) with the organisation (Freeman 1984). Different stakeholders are considered the most powerful resources of the organisation as they influence the decision process. Sustainability reporting is a strategic approach of the organisation that denotes stakeholder's participation and reduces information asymmetry. Moreover, it is considered that the organization taking into account stakeholder's requirement to perform better performance than those that do not. Therefore, CSR disclosure is the result of stakeholder's pressure (Gray et al. 2009; Comyns 2016; Masud et al. 2017). Freeman et al. 2010 define the stakeholder theory as fundamentally a theory about how business works at its best, and how it could work. It is descriptive, prescriptive and instrumental at the same time it is managerial. It is about value creation and trade and how to manage the business effectively (p. 9). Stakeholder's pressure motivates firms for better investment and policies on environmental performance (de Villiers et al. 2011). Moreover, it is considered that environmental reporting is the medium between society and stakeholder for the 
ecological responsibility of the firms. Baral and Pokharel 2017; Perrault and Clark 2016 and Masud et al. 2018a, b stated that CSR reporting enhance firms accountability, transparency, and reputations to the stakeholders. Additionally, the prior study points that stakeholder engagement, awareness and perception improve SR accountability of the organization (Momin 2013; Belal et al. 2015).

\section{Legitimacy theory}

Legitimacy theory defines the social construct between society and organisation. Doing business in the society firms have to follow the social norms, values and rules, otherwise faces legitimacy threat. Legitimacy also defines the organisational resources which increase societal support (Dowling and Pfeffer 1975) and managerial capability over the legitimation process (Suchman 1995). Suchman defines legitimacy as "a generalized perception or assumption that the actions of an entity are desirable, proper, or appropriate within the same socially constructed system of norms, values, beliefs and definitions" (1995, p. 574). CSR disclosure considers a strategic tool of the firms to minimize the legitimacy gap within the society and stakeholders. Moreover, CSR disclosure is the response of the stakeholders' concern over controversial environmental and social issues. For example, firms disclose not only positive but also negative incidents in the disclosure pattern that increase trust and reduce legitimacy threat over controversial issues. Patten 2014 classified economic and social legitimacy whereas, Richardson 1985 and Ashforth and Gibbs 1990 discussed symbolic and substantive legitimacy as a technique to reduces legitimacy threats. Belal et al. 2017 stated that firms used later two types of legitimacy techniques as a combination to demonstrate conformity with social values and norms. Therefore, CSR disclosure removes social and political pressures and assures stakeholders for quick actions. Javeed and Lefen 2019 and Yunis et al. 2018 exerts that MNC executives use SR to gain short term social legitimacy in Pakistan rather than long-term strategic view.

\section{Political cost theory}

Political cost theory defines different socio-political factors that influence the organisation regarding decision making. Watts and Zimmermann define political cost as "the political sector has the power to effect wealth transfers between various groups. Certain groups of voters have an incentive to lobby for the nationalization, expropriation, breakup or regulation of an industry or corporation. ... ... By avoiding the attention that "high" profits draw because of the public's association of high reported profits and monopoly rents, management can reduce the likelihood of adverse political actions and, thereby, reduce its expected costs" (1978, p. 115). Business management must consider political factors regarding social and environmental policy and investment. Especially, in the weak economy, political intervention is highly evidenced because of political and family controlling nature of business (Shirodkar et al. 2016; Uddin et al. 2016; Muttakin et al. 2018). Moreover, in the developed economy political control is for the sake of the economy as well as stakeholders' interests. Therefore, business organisations have to concern on different socio-political factors that raise cost and controversy. CSR disclosure considers an imperative technique to reduce political cost and legitimacy. Moreover, CSR disclosure posits significant information regarding social and environmental 
initiatives that reduce political pressure. Moreover, the most recent study of Masud et al. 2018a, b states, South Asian firms (Bangladesh, India and Pakistan) are highly motivated to disclose CSR disclosure because of minimizing political pressures. It is also argued by Muttakin et al. 2018 that political management eschews stakeholder pressure that discourages CSR disclosure.

\section{Signalling theory}

Signalling theory entails to the information asymmetry between organisation and market forces (Connelly et al. 2011; Bae et al. 2018; Taj 2016). The theory focuses on how an organisation deals with different signals. Information asymmetry causes potential conflicts between management and agents that increase reputational problems in the market. CSR disclosure reduces the potential conflicts and coveys positive signals to the markets. For example, the firm's investment and policy decision regarding social and environmental areas send a positive and effective signal in the market that increases firm value and stock price. Signalling theory also explains management intention and willingness on CSR initiatives (Bae et al. 2018). In the signalling theory feedback from market, components are very crucial because positive feedback signals reduce information asymmetry gap and enhance management confidence. On the other hand, a negative signal provides necessary corrective actions against strategic planning. Connelly et al. 2011 and Taj 2016 narrate that higher quality firms convey honest signals than lower quality firms. The most recent study of Bae et al. 2018 finds South Asian business management (Bangladesh, India and Pakistan) uses sustainability disclosure to reduce information asymmetry and send/receive an honest signal.

\section{Literature review}

Sustainability reporting (hereafter SR) is still in its infancy and the level of environmental and social disclosures are inadequate, and of a poor standard in developing countries (Belal and Cooper 2011). Despite the low level of reporting in emerging and developing countries, the growth rate is stronger than developed countries as confirmed by a survey commissioned by the GRI, which revealed that the number of reports has quadrupled since 2005 (Guardian 2011). Likewise, the KPMG (2013) survey revealed an exceptional growth in the practice of SR in the emerging and developing economies. The survey records a dramatic increase in SR rates, especially in the Asia Pacific where almost three quarters $(71 \%)$ of companies now publish sustainability reports. Moreover, the recent studies of South Asian region; Masud et al. 2018a, b, 2017; Bae et al. 2018; Hossain et al. 2017 (Bangladesh), Mahmood et al. 2018; Ehsan et al. 2018; Yunis et al. 2018; Lone et al. 2016; Ali et al. 2017; Malik and Kanwal 2016 (Pakistan), Shamil et al. 2014; Dissanayake et al. 2016 (Sri Lanka), and Goel 2018; Patel and Rayner 2012; Ezhilarasi and Kabra (2017); Yadava and Sinha 2016 (India) explores the increasing nature of CSR disclosures in the region.

Despite the tremendous growth, research on SR focused mainly on developed countries with very little research available in developing countries (Amran and Haniffa 2011; Belal and Owen 2007; Islam and Deegan 2008; Sawani et al. 2010; Matten and Moon 2008). Much of the earlier and the current research are descriptive in nature and follow or replicate similar research in developed countries on sustainability practices. 
They are mainly based on secondary data and use quantitative content analysis to find out the extent of reporting and its determinants (e.g. Abayo et al. 1993; Belal 2000, 2001; De Villiers and Van Staden 2006; Imam 2000; Belal et al. 2015). There are two common findings of this kind of research: first, companies operating in developing countries provide limited disclosure of social and environmental performance and second, there are inconclusive and inconsistent results about determinants which range from company size, performance, industrial affiliation, culture, ownership structure, and board composition (Belal and Momin 2009; Islam 2010).

In recent years, researchers have moved away from a quantitative approach and explored the perception of corporate managers and stakeholders through interview-based studies. Empirical studies in developing countries highlight the importance of studying societal (socio-economic, political and cultural) context as part of the institutional environment that significantly impact the disclosure practices and organisational rationales in developing countries. These contexts represent various structural and cultural conditions prevailing in a particular society. As argued by Islam and Deegan (2008), explaining this context can unbox various social and environmental expectations and pressures being exerted on an organisation and help in understanding their motivations. Various conditions that have been identified in the literature include: dependence on foreign aid, high level of poverty, corruption, inequalities, social exploitation, ownership concentration, strong ties between business interest groups and political parties, lack of awareness and interest in sustainability matters, lack of education, low media pressure, lack of civil society activism, lack of regulation, weak government structures, lack of political will, and lack of enforcement capabilities (Ahmad 2010; Belal 2008; Belal and Cooper 2011; Mahadeo et al. 2011; Momin and Parker 2013). These conditions provide opportunities and constraints for the practice of SR in these countries. In their study, Belal and Cooper (2011); Hoque et al. 2016 and Belal et al. 2017 associated lack of legal requirements, lack of awareness, lack of resources, lack of performance and the associated fear of bad publicity as necessary explanations for the absence of social reporting in Bangladesh. The recent study of Uddin et al. 2016 and Muttakin et al. 2018 argues political connectedness of corporate management reduces CSR disclosure pressure from stakeholders in Bangladesh.

The recent study of mixed research (qualitative and quantitative) on CSR in the developing countries Nurunnabi 2016 and Hossain et al. 2017 (Bangladesh); Mahmood et al. 2018 and Ehsan et al. 2018 (Pakistan) states that CSR disclosure is comparatively increasing in the region and it has a significant relationship with corporate governance elements. Further, Hossain et al. 2017 find reactive pressure from powerful stakeholders and proactive motivation are behind CSR disclosure in Bangladesh. Hoque et al. 2018 posit that still business management of Bangladesh are less concerned with CSR business goals and believe CSR performance like a cosmetic and face-saving marketing strategy. Shirodkar et al. 2016 evidence that MNC in India compromising CSR because of reducing political cost and pressure. Furthermore, Goel 2018 provides evidence of the benefits of reform corporate governance rules of the Indian and the mandatory CSR disclosure provision that leads to increased financial performance also. In addition, Dissanayake et al. 2016 and Shamil et al. 2014 find Sri Lankan companies CSR disclosure is comparatively scattered and insufficient because of policy level acknowledgement. Bissoon 2018 finds Mauritius MNC hotel groups mostly disclose positive news 
rather than negative. Husted et al. 2018 argue that in Latin America CSR disclosure is lacking but current institutional and socio-economic factors constantly influence corporate governance to disclose more and more information. Moreover, $\mathrm{Hu}$ and Loh 2018 investigate the CSR disclosure of Singapore and posit sound regulation playing the major role of higher disclosure. It is also evident that CSR disclosures reduce information asymmetry and send a faithful signal to the stakeholders and market regarding organization sustainable initiatives (Bae et al. 2018).

Momin and Parker (2013) also associate lack of reporting with the complex cultural business and regulatory environment in Bangladesh that discourages corporate selfpraise, fails to require and enforce reporting and promotes a climate of secrecy in business dealings and accountability. Very few studies confirm (e.g. Mahadeo et al. 2011) some influence of local cultural conditions as an enabler of SR which is mainly driven by outside forces (Belal and Owen 2007; Islam and Deegan 2008; Momin and Parker 2013; Belal et al. 2015). Islam and Deegan (2008) observe that the pressures being placed on the Bangladeshi clothing industry by powerful stakeholder groups (multinational buying companies) were reflected in the disclosure practices of the industry. In the presence of these external pressures, the main motivation was found to be economic rather than concerns for social responsibility from the ethical perspective. Naeem and Welford 2009 said both Bangladeshi and Pakistani government and civil society are unable to mandate a robust CSR strategy to business management.

Some important insights are provided by researchers that have explored the perception of non-managerial stakeholders. Different studies of Belal and Roberts 2010; Nurunnabi 2016; Hossain et al. 2017; Belal et al. 2015; Masud et al. 2017, 2018a, b; Majeed et al. 2015; Mahmood et al. 2018; Malik and Kanwal 2016; Goel 2018; Hu and Loh 2018, Masud and Hossain 2012, confirms that stakeholders favoured mandatory reporting and consider SR as an important mechanism to discharge accountability in a democratic and transparent manner. Stakeholders view the current practice as having failed to meet expectations. They were found to be sceptical about corporation motivations and perceived profit motive and economic reasons as the main driver. The fact that the majority of the companies in export business make such disclosures, and that they are not involved in stakeholder engagement, makes these motives apparent. However, Belal and Roberts (2010) argue that mandatory reporting may result in unintended consequences without enhancing and investing in enforcement capabilities of regulatory agencies. These views are confirmed by Momin (2013) in a similar study of the perception of non-managerial stakeholders. In his study, NGO executives considered SR practice as ad-hoc and a public relation exercise. Although they perceive SR as a process of corporate accountability and showed interest in lobbying other pressure groups and encouraging regulation, NGO executives assign lesser significance to disclosures (which they perceive as corporate commercials) and are more concerned with substantive actions and the finding is consistent with Goel 2018. However, Ehsan et al. 2018 documented in the mixed method study that general CSR order 2009 and voluntary CSR regulation 2013 have a significant impact on the Pakistani firms SR performance.

\section{Research methodology}

According to O'Dwyer et al. 2005 the use of qualitative methods is more appropriate for capturing the stakeholders' perceptions as well as the context in which they are 
held. Taking the interpretive approach, we explored the multiple realities of various stakeholders regarding different aspects of sustainability reporting practice in Pakistan. We interviewed 20 individuals from Pakistan who were identified as main actors directly or indirectly involved in the SR practice (see Table 1). Respondents were selected on the criterion of availability, industry best practices, and prior professional experiences.

In the frame of the research criteria, the interview was conducted between 2013 and 2017 following several rounds. The first round of interviews took place in 2013 followed by the second round of interviews in 2015. During the second round of interview, we have rearranged the participants based on the result of the first round of interview (e.g. firm selection). In order to clarify a few points during the writing process of the paper, the third round of interview with selected interviewees of earlier rounds was conducted in the year 2017. It is also mentionable that interview based research specially in the developing country is a difficult task because of lack of transparency and culture of hiding information (Belal et al. 2015; Momin 2013; Yunis et al. 2018.). A brief profile of the interviews showing the status of interviewees and nature of their organisation and location is given in Table 1. The key informants, in this case, were the most senior person in the organisations who appeared to be knowledgeable about various issues related to SR in general as well as specific to their organisation.

The duration of the interviews ranged from $30 \mathrm{~min}$ to $2 \mathrm{~h}$. All interviews started with a brief introduction of the research project and an outline of the objectives of the

Table 1 List of Research Participants

\begin{tabular}{llll}
\hline No. & Interviewee Designation & Nature of Organization & Location \\
\hline 1 & Commissioner & Regulatory Body & Islamabad \\
2 & Director Enforcement & Regulatory Body & Islamabad \\
3 & CEO & Stock Exchange & Karachi \\
4 & Country Head & Foreign Professional Accounting Body & Lahore \\
5 & President & National Professional Accounting Body & Lahore \\
6 & Partner & Management Consultancy & Islamabad \\
7 & Director & Consultancy Firm on CSR and & Islamabad \\
8 & Professor & Sustainability & \\
9 & Project Manager & Private Sector University & Karachi \\
10 & Country Head & Local Environmental NGO. & Islamabad \\
11 & Research Associate & Foreign Environmental NGO & Lahore \\
& & Policy Institute on Sustainable & Islamabad \\
12 & CEO & Development & \\
13 & Founder & Institute on Corporate Governance & Karachi \\
14 & Manager HR and CSR & First Enabler of CSR in Pakistan & Lahore \\
15 & Head of Corporate Communication & National Petroleum Company & Rawalpindi \\
16 & Manager, Corporate Communication and Public & Multinational Chemicals Company & Karachi \\
17 & Affairs & Head of Corporate Commi \\
18 & Executive Corporate Communication and CSR & National Fertilizers Company & Lahore \\
19 & Managing Director & State Owned Oil and Gas Company & Islamabad \\
\hline & & Multinational Tobacco Company & Islamabad \\
\hline
\end{tabular}


interview. With the permission of the interviewees, a tape recorder was used to record each interview. All recorded interviews were transcribed. It was agreed that neither the interviewees nor their respective organizations would be identified when quoting them. Following a semi-structured interview protocol, interview questions encouraged openended responses that allowed interviewees to respond from their own perspective. Interviews were conducted with managerial and non-managerial actors regarding their views on the following issues.

1. Drivers and Barriers of Sustainability Reporting.

2. Sufficiency of Current Regulation and Enforcement

3. Need and Relevance of Guidelines and Standards

4. Perceived Benefits of Sustainability Reporting

5. Level of Stakeholder's Engagement

6. Level of Transparency and Accountability

The above procedure generated over 100 pages of data. A summary of each interview was prepared and analysed. These summaries helped to identify the contrasting perspectives of different stakeholder groups, the most commonly occurring themes and differing viewpoints and allowed us to situate the responses within prior research on SR in a developing country context.

\section{Corporate sustainability reporting in Pakistan}

Corporate sustainability reporting currently falls under the ambit of voluntary reporting in Pakistan. Currently, there is no specific regulation that governs corporate sustainability and its reporting in Pakistan. However, there is a wide variety of laws, regulations and policies that in one way or the other emphasizes the requirements for corporate sustainability initiatives (social and environmental) including reporting of such initiatives (Balkhi 2010). The most salient among them is the Pakistan Environmental Protection (1997), the SECP General Order for Corporate Social Responsibility (2009), the Code of Corporate Governance (2012) and the Corporate Social Responsibility (CSR) Voluntary Guidelines (2013). In addition, there are several guiding principles and frameworks in the form of multi-stakeholder initiatives that facilitate corporate sustainability and reporting in Pakistan. Most salient among them include, Pakistan Compliance Initiative (PCI), Responsible Business Initiative (RBI), Global Reporting Initiative (GRI), United Nations Global Compact (UNGC) and The International Federation of Accountants (IFAC) Sustainability Framework.

Corporate Sustainability Reporting is still in infancy in Pakistan (Malik and Kanwal 2016; Mahmood et al. 2018). The practice of SR is emerging as the next level reporting for those companies which have some reporting background on social responsibility and environment. Very few listed companies are reporting on sustainability-related matters either in their annual reports or in the form of stand-alone sustainability reports. According to a survey of Deloitte (2012) only 19 companies listed on the KSE 100 index were either issuing standalone sustainability reports or presenting certain information on sustainability as part of other information within their annual report. Similarly, the number of entries submitted for ACCA-WWF Pakistan Environmental Reporting Awards (PERA) confirms that currently, around 20 companies submit their 
information for best sustainability reporting awards. When the study considered against the backdrop of the total number of registered companies (around 15000) and especially the total number of listed companies (around 590) this is a very small number and there is a need to investigate the views of main actors involved in SR on the current state of affairs so that some recommendations can be made for further improvement. Recent studies on CSR disclosure focus on listed firms performance; Nazir 2010 investigates CSR disclosure of fertilizer industry; Nazish 2014 explores regulatory importance of CSR disclosure; Malik and Kanwal 2016 study on listed pharmaceutical firms CSR disclosure and financial performance; Lone et al. 2016 finds increasing nature of CSR disclosure since 2013 because of CSR voluntary guidelines; Naeem and Welford 2009 compares the CSR disclosure performance between Bangladesh and Pakistan; Sharif and Rashid 2014 make a study of CSR disclosure on commercial banks; Fayyaz et al. 2015 investigates donor funded CSR initiatives; Mahmood et al. 2018 conducts an interview and content based study of CSR on corporate governance; Ehsan et al. 2018 investigates a multi-method approach of CSR disclosure on listed firms while Yunis et al. 2018 documents CSR performance of MNC. Moreover, Iqbal et al. 2018 found the mediating role of CSR in the authentic leadership of Pakistani banking sector. This discussion confirms that CSR disclosure is significantly growing in Pakistan. Additionally, the latest study of Khan et al. 2019 documented that board diversity variables like; gender, nation, tenure and educational qualification has a significant influence on CSR disclosure of Pakistani firms.

Many different actors are directly or indirectly involved in sustainability reporting. There are several national and international organisations that are playing their role in the emergence and development of sustainability practices in Pakistan. These social actors are performing different roles (e.g. Policymakers, regulators, enablers, pressure groups, advocacy, consultants and reporters). These social actors take each other into account for the development of practice and collective rationality of SR, through the processes of communication, contestation and coordination. In this context, one of the main actors is in the reporting firm itself. In addition to reporting firms, other actors of interest are NGOs, academics, regulatory bodies, business associations, stock exchanges, professional accounting bodies, professional services firms and consultants. The remainder of this section reports the empirical findings from the interviews that explored the social actors' views on the current state of sustainability reporting. In particular, we describe the drivers and barriers of sustainability disclosures provided by our interviewees. Also, the main actors' view about sustainability related regulation and standards, perceived benefits, level of stakeholder engagement and transparency are provided below.

\section{Findings and discussion}

\section{Sustainability awareness}

According to most of the interviewees, there is very little awareness of the concept of social responsibility and sustainability among businesses as well as their stakeholders. This has been viewed as a major constraint for the emergence of SR in Pakistan. One of the interviewees, who was working on policy and advocacy for sustainability, draws attention towards the lack of awareness among consumers: 
"In our country, if you keep a product one rupee less in price, then people will buy it and will not notice whether this is a green product. There isn't awareness in our consumers. Even if you talk to the educated class, you will not hear anybody saying that I have bought this product because it is a green product or because this product is from the factory which is CSR compliant. What you will hear is that they have bought the product because it is an international brand. So, there are two extremes. One of them will say that we're saving money and the other will say that it's a better brand obviously. Both extremes don't bother whether this green product or not?" (Research Associate, Policy Institute in Sustainable Development).
The arguments are driven from the stakeholder perspectives.

The above interviewee also draws attention towards limited awareness of the concept among business professionals. Given the fact that the phenomenon is comparatively new to the business community, many of the businessman and managers are not familiar with its processes and requirements. This argument is also consistent with other similar countries like Bangladesh, India, and Sri Lanka (Imam 2000, Belal et al. 2015, 2017, Momin 2013 (Bangladesh); Gatti et al. 2018; Goel 2018 (India); Shamil et al. 2014; Dissanayake et al. 2016 (Sri Lanka) while they reported that sustainability concept is very vague, scatter and in the formal stages. $\begin{array}{ll}\text { "When you talk to the general managers of those companies } & \text { The statement posits the theoretical lens of } \\ \text { who have ISO certifications for environmental responsibility } & \text { stakeholders and institutional perspectives. }\end{array}$ and quality, you will realize that they have no idea about what the certification/standard is actually for. When asked about any particular certification (like quality standards) they will tell you some different standards number from their own side and about the paperwork: it was hilarious at times because in most cases that was not the standard to which they were complying. So, that's what I found that too much is missing in our ... education in business is very less, there are very few who are aware of it and there are very few who are working on it." (Research Associate, Policy Institute in Sustainable Development).

Another interviewee, while agreeing with the lack of awareness among business professionals, attributes this to the lack of education and research culture in universities.

"Our universities and business schools do not teach CSR as a subject and there is no research being done in this area" (Professor, Private Sector University).

Lack of professionalism is also prevalent in business associations where businessmen with little awareness of the issues become elected members of the committee that is responsible for various tasks related to sustainability issues.

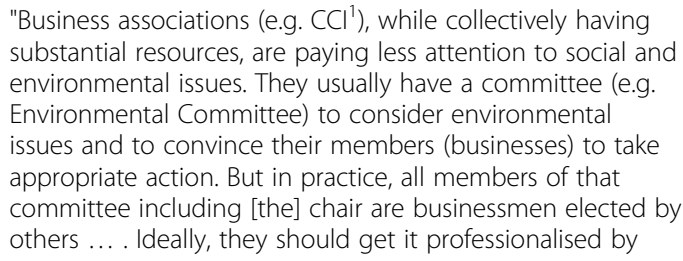


Findings and discussion (Continued)

hiring four to five professional people and allocate [a]

substantial budget for its activities. But that is not the case

..." (Country Head, Foreign Environmental NGO)

However, in recent years there has been an increasing trend towards creating awareness of these issues at various levels (Nazish 2014; Malik and Kanwal 2016; Sharif and Rashid 2014; Mahmood et al. 2018; Ehsan et al. 2018; Yunis et al. 2018). The recent CSR regulation and gender diversity strongly influence the Pakistani firm's sustainability reporting practices. It is also evident that institutional coercive and mimetic pressures exert firms to be more socially responsible. In 2012, SECP came up with CSR voluntary guidelines after a series of roundtables with various stakeholders. These guidelines set an important milestone in creating a vibe among the business community and directing their attention towards the concept of CSR. According to the senior official of SECP:

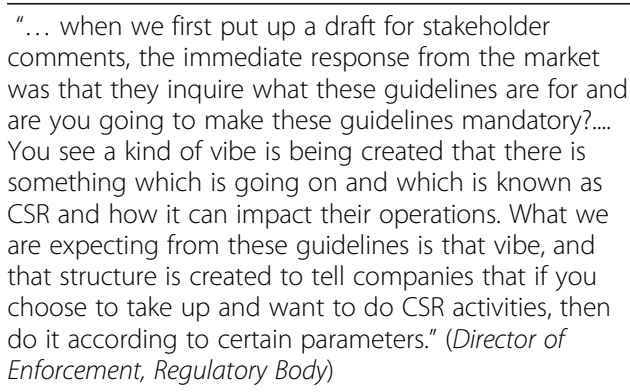

After issuing those guidelines, SECP is now working with different organisations (for example PICG and RBI) for creating awareness in the form of stakeholder sessions among the business community about the benefits of being involved in responsible business. According to the stakeholder theory, sustainability disclosure create accountability and transparency of the organisation that ultimately empower stakeholder's engagement and reduces agency cost. On the other hand, institutional theory broadly explain the importance of voluntary or mandatory regulation and standard that is the way of organisational isomorphism. Our argument is consistent with the lines of stakeholder and institutional point of view as well as the findings of Hossain et al. 2017; Mahmood et al. 2018; Masud et al. 2018a, b. Moreover, the most recent study of Khan et al. 2019 and Mahmood et al. 2018 found that board diversity (women board member, age, nationality, tenure) and the CSR committee has a significant impact in the sustainability disclosure of Pakistan.

\section{Sustainability interest}

While awareness is an issue, there is also a lack of interest in the concept of sustainability at different levels which is reflected by the number of interviewees, especially from the community organizations and the accountancy profession. According to one of the interviewees: 
mainstream political parties are captured by elites (mainly big businessmen and feudal lords) which are at the worst corrupt and at best see no direct benefits of being socially responsible ....... [The] spirit of social and environmental responsibility was totally absent from the manifesto of mainstream political parties in the recent general elections. I found their manifesto very vague regarding the responsibility and accountability of the business towards society and [the] environment.......There is no public demand for these concepts and that could be the reason why political parties ignore them, as talking about these concepts will not give them any popularity since the general public is not aware of these issues." (Research Associate, Policy Institute in Sustainable Development)

political cost theory with sustainability disclosure.

Another interviewee, while agreeing with the lack of interest at the political level, explains that the same thing can be observed at the socio-cultural level. At this level, it can be explained in terms of an overall short-termism approach prevalent in Pakistani society. While sustainability is necessarily a long-term concept, most of the people in Pakistan believe in a short-run approach. This short-run approach can be associated with the way people have grown up and also with the economic and political instability and the associated uncertainty.

\begin{tabular}{l}
\hline "The dilemma of our nation is that we are running our \\
affairs on a day-to-day basis. We never think and talk about \\
sustainability. Sustainability is long run but we're a short \\
run. We see today's profit; we don't notice tomorrow's \\
survival ...... I think it's also because of instability and \\
uncertainty that [the] state provides. We don't know what is \\
going to happen tomoretical perspectives. \\
is yours .... you don't know whether it [there] is going to \\
be a tomorrow to catch anything." (President, National \\
Professional Accounting Body)
\end{tabular}

Because of these reasons, concepts like social responsibility and sustainability are not high on the business agenda. Therefore, these concepts are still in their infancy and very few companies are giving attention to these concepts. Even those who are practicing things like social responsibility and sustainability might have some other reasons for doing so and hence, are driven by other factors. In the corrupt economy, political cost is huge also it is open secret as there is a lack of institutional transparency and accountability. Furthermore, unawareness of stakeholder creates legitimacy gap between society and organisation. Moreover, tax and legal exemptions substantially legitimate political cost (Watts and Zimmermann 1978; Masud et al. 2018a, b). Prior study of Watts and Zimmermann 1978 stated that political cost mostly depends on the size of the organization. These findings of corresponds with the arguments of political cost as well as legitimacy theory (Shirodkar et al. 2016; Uddin et al. 2016; Muttakin et al. 2018). It seems in Pakistani business management considers SR as a short period philanthropic tools rather than a long period strategic tool. Furthermore, Yunis et al. 2018 found Pakistani MNC focuses on discretionary CSR rather than economical and legal that is consistent with our political cost and social legitimacy argument (see also Muttakin et al. 2018). 


\section{Incentives and awards}

There is a consensus among many interviewees that incentivising companies, by recognising their efforts towards reporting on sustainability, in the form of reporting awards is one of the main drivers for the emergence and development of SR in Pakistan. This is similar to the findings of a number of other studies in emerging and developing economies (Amran and Haniffa 2011). According to the corporate manager of a multinational company reporting on sustainability, these awards play an important role as they ".... specify the criteria for good reporting and provide you with the necessary incentive for reporting." (Head of Corporate Communication, Multinational Engineering Company).

However, some interviewees highlighted that one should be cautious when looking at the influence of these awards on the practice of SR. While increasing the incidence of reporting, these awards were having a negative influence on increasing the transparency and improving the sustainability performance of the organisation which is the real purpose of such reporting. Companies started reporting just to be nominated and win these awards. According to an interviewee:

\footnotetext{
".... people want that [the] report should be flowery so that they can win awards .... [A] few companies make report $[\mathrm{s}]$ just for getting awards... Interestingly many times it happens that when corporate managers approach us to help in reporting and when I explain the process, that spans around 6 months for deciding on [a] number of indicators, gathering of information and internal verification, so that we can ensure that we are realistic and that something wrong is not mentioned, they say no no we have to publish it earlier so that we can be nominated in awards." (Founder, First Enabler of CSR in Pakistan)
}

The argument posits with the legitimacy and signalling theoretical understanding.

The same interviewee pointed out that this desire for getting awards has created a market for award ceremonies and the current situation is that there are several award companies operating in Pakistan which are distributing awards without any criteria for best reporting.

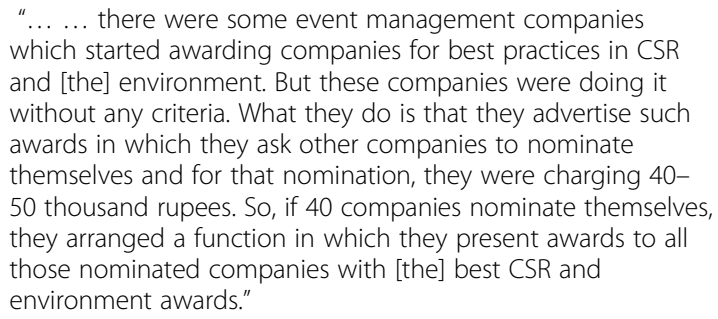

At the cultural level, this desire for getting awards can be attached to the culture of a show-off and ego-satisfaction prevailing in Pakistani society.

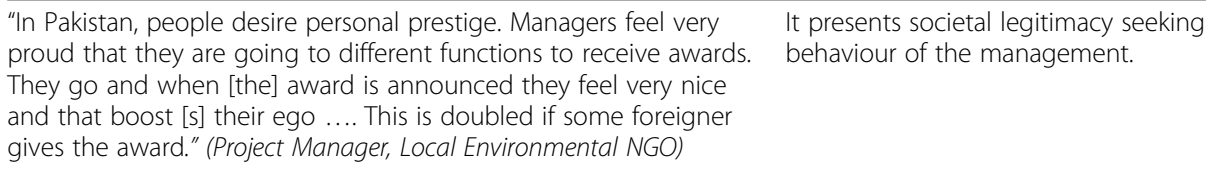

The argument posits with the legitimacy and signalling theoretical understanding. 
Apart from reporting awards, some interviewees believed that reporting companies and the non-reporting companies shall be encouraged towards SR through other incentives.

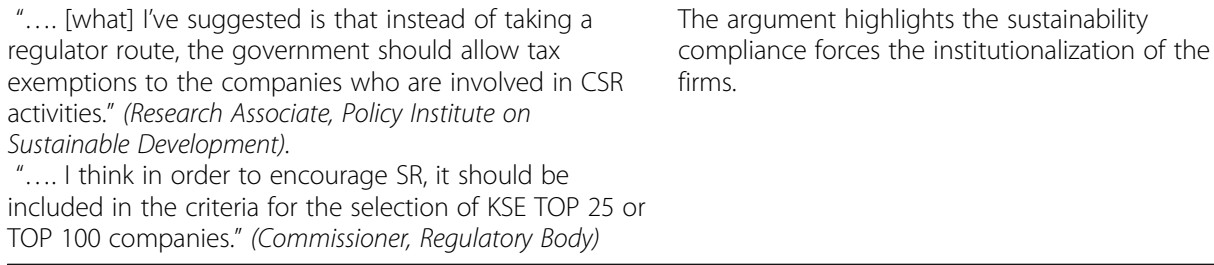

There is a perception among interviewees that in the absence of any other direct benefits of SR, awards and/or other incentives are the main encouragement for reporting. In the absence of such encouragement and in the presence of more regulation, companies may quit the stock market. This has been elaborated by the senior official of the leading stock exchange in Pakistan.

\begin{tabular}{ll}
\hline "The real success will depend on when, in addition to & Signalling theory sends a positive or negative signal \\
regulation [s], we are able to incentivize [the] corporate & to the market based on sustainability disclosure. \\
sector with the benefit of reporting .... Otherwise & \\
because of more compliance and its associated costs as \\
compared to the benefits, [a] larger number of \\
companies will exit the stock market which means that \\
you are going to encourage the undocumented \\
economy." (CEO, Stock Exchange)
\end{tabular}

Also, there is a perception that making such reporting mandatory may lead to unintended consequences in the form of an increase in corruption and symbolic and tick-box compliance.

"Non-reporters shall be encouraged through incentives because force The argument posits on mandatory never really works here in this country. Non-reporters will find a way regulation for sustainability. around if they do not really want to do it. It will be all on paper, but it will not be in practice." (Head of Corporate Communication, Multinational Engineering Company).

In the theoretical argument, CSR disclosure reduces the legitimacy gap between stakeholder and firm, and help to restore distorted images and accountability. Higher CSR and environmental performance send honesty signal to the market and stakeholders that enhance the firm's value and visibility. These discussions argue that perceived SR benefits increase the social legitimacy that swells firm's reputation and leads to be a sustainable firm. On the other hand, social recognition sends positive and trustworthy signals in the market that enhance market reputations and visibility (Bae et al. 2018). But, SR recognition is completely scattered and unpleasant in Pakistani business environment that induces legitimacy and political threat to the business organisations that also raises organisational incapability and expertise in the area.

\section{Foreign influence}

Involvement of foreign institutions has implications for creating demand, for sustainability and its reporting, which is missing in the local societal context. Also, 
these are influencing the supply side in the form of institutional and professional development and by raising awareness. These can be easily categorised as drivers of SR in Pakistan. Among others, the influence of foreign buyers and investors is more important for enforcing the realisation among the business community in Pakistan towards environmental management and social responsibility (Yunis et al. 2018). Foreign buyers and investors are seeking businesses who not only comply with quality standards but also standards related to social responsibility and environmental sustainability.

"SR is the source of competitive advantage in the international

The argument complies with the marketplace, whether that be Pakistani companies investing institutional theoretical discussion. overseas, directly selling their products abroad or supplying multinational companies. Customers, particularly those in European

markets, increasingly reward companies which disclose their sustainability impacts." (Triple Bottom Line)

Sustainability is becoming an important business concern especially for businesses in the export sector and those who decided to raise capital through selling their shares in the international market. In this way, foreign buyers and investors are potentially the sources of market institutions shaping sustainability practices. The following quote from the ACCA research study elaborates this:

"Sustainability is the requirement of foreign brands. As the requirements come, people will have to follow such practices. If you do not follow those practices, you will be out of business ... I will follow environmental and social laws only because the European Union wants me to. It is an external pressure - a compulsion."

These regulative pressures are perceived to be even more likely to occur in the future where they would affect the global competitiveness of Pakistani companies. This will further raise the importance of sustainability practices as otherwise Pakistani exporters may lose business.

"I still feel that so far we live in [a] Pakistani context but very soon we have to see things in [the] international context like our exporting industries, after GSP plus status, have to do

The argument is consistent with the institutional and legitimacy theoretical compliance for social and environmental issues. Regional competitors (like India and Bangladesh) will definitely lobby against Pakistani exporters, so buyers will focus more on these issues." (Founder, First Enabler of CSR in Pakistan).

More specific influence on the emergence of SR comes from professional accounting bodies and multinationals. The role of professional associations in driving SR is described in a separate section. However, according to the corporate manager of a multinational firm, they are playing an important role in creating demand for sustainability and it's reporting by showcasing their practices and setting examples for local companies.

"We have always been committed to sustainability. That is part of our corporate philosophy ... We try to set an example for other local industries by adopting sustainable business practices." (Manager, Corporate Communication \& Public Affairs, Multinational Chemicals Company).
The argument is consistent with the stakeholder theory. 
Organisation faces competition in the sound institutional environment that leads to mimic SR strategy. The discussion focuses on coercive and mimetic pressures to validate SR practices. Cultural differences and foreign organisations domestic norms encourage practicing more CSR and SR initiatives (Shirodkar et al. 2016) if there are specific regulations. Moreover, holistic SR framework mitigate stakeholder and social pressure. Therefore, foreign influence helps to achieve institutional isomorphism. The most recent study of Khan et al. 2019 documented that foreign board diversity significantly influences Pakistani firms CSR reporting.

\section{Professional associations}

Overall, professional associations are driving the SR agenda in Pakistan. Professional associations are performing this role in several ways which include consultancy projects, reporting awards, seminars, workshops, conferences, and technical articles. In fact, the very first sustainability report was prepared by a company on the strong advocacy of RBI that was interested in promoting SR in Pakistan. Among other notable influencers include CSRCP which organized a workshop and PICG which organized the conference on SR. These organisations and events played an important role in providing a platform for SR awareness and practice in Pakistan. During interviews with the corporate managers, the influence of these organizations and events was quite evident and they did mention it as one of the major sources of their knowledge and interest.

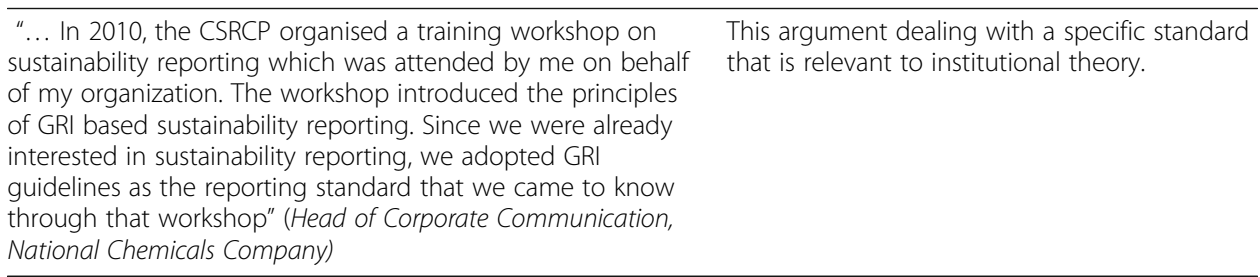

Among all professional associations, accountancy professional bodies (ACCA, ICAP, and ICMAP) are now assuming the lead role in Pakistan in spreading awareness and training their workforce on the environment, sustainability and governance matters. These bodies are involved in the professionalization of their existing members through CPD activities and technical articles. Further, these matters are being incorporated into the syllabus so that the next generation of accountants and business professionals are well-informed and can impact the practices of the institutions they work for. This has been revealed by the head of a global professional accounting body operating in Pakistan as:

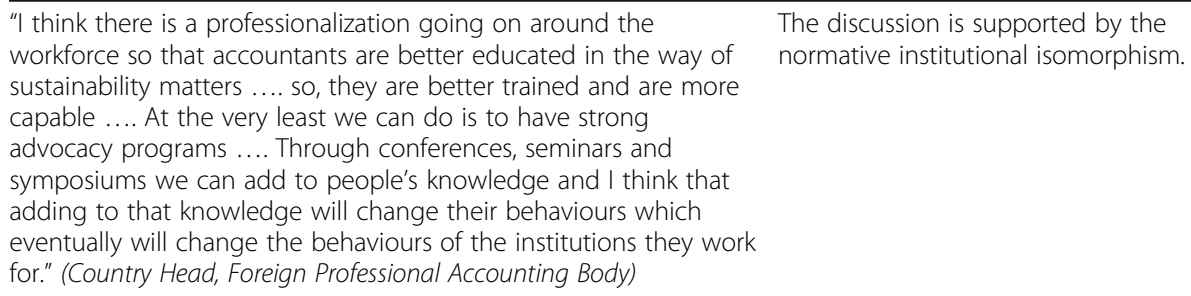

The discussion is supported by the normative institutional isomorphism. 
Overall, professional associations are spreading SR disclosure and are an important source of normative pressures for the emergence and development of SR in Pakistan. In the liens of normative institutional theoretical discussion, the above argument is consistent with the best practice of corporate professionalism that leads SR. The argument posits that professional accounting bodies can play a vital role in Pakistan for the further development and encouragement of SR movement in corporate management. Moreover, this discussion is consistent with the finding of Belal et al. 2017 in the context of Big 4 audit firms of the country.

\section{Regulation and enforcement}

Differences of opinion exist among different social actors over whether current regulation is enough and whether SR should be made mandatory. Some interviewees believed in mandatory reporting for the sake of public interest especially in the context of a country which is characterised by low stakeholder pressure.

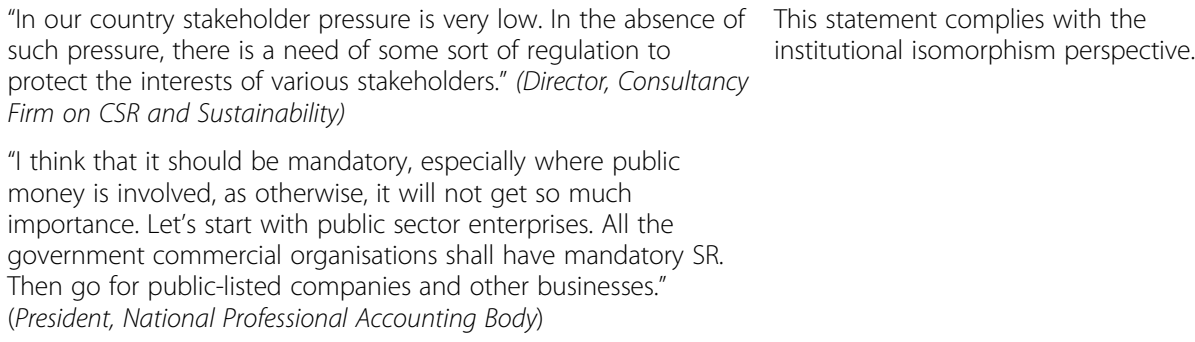

Another interviewee described the need for mandatory reporting as otherwise "it will provide sufficient justification, to managers, for non-disclosure" (Professor, Private Sector University). A large number of businesses perceives it as an unnecessary activity and a costly affair. The prevailing managerial attitude is: we will only comply if we are legally bound to do so. But at the same time, they do not want regulators to make it mandatory.

\footnotetext{
"We are not reporting on CSR/sustainability as it's currently voluntary. We This statement complies with the will do it when it becomes mandatory. Why ... put extra burden on our institutional theory. shoulder [s]. There is no appreciation of extra work; rather there is criticism." (Executive Finance, Multinational Tobacco Company)
}

Making SR mandatory, however, is not viewed as a panacea by some interviewees. According to them, if SR is made mandatory, it can open new doors for corruption as the state apparatus lacks resources and is very weak in enforcement.

\footnotetext{
"I think it should be voluntary as if it is made mandatory then we have issues of capacity and corruption. [What] all [of] the companies will do is that they will hire someone for writing a report. Whether that report is realistic or not, who will determine this? Because of lack of state interest, relevant government departments (for example $\mathrm{EPD}^{2}$ ) lack resources and are very weak. Despite ... doing good work with limited resources, officials in these departments are very often involved in corrupt
}

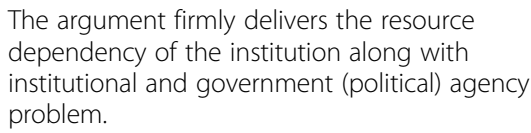

The argument firmly delivers the resource dependency of the institution along with institutional and government (political) agency problem. 
Findings and discussion (Continued)

practices. They let businesses do whatever they want to, for monthly ${ }^{3}$ returns. This will not help in achieving the objectives of reporting which is to improve sustainability performance." (Country Head, Foreign Environmental NGO)

This is due to patronage-based appointments of bureaucracy by ruling elites, which either protect the interest of these elites or work for their self-interest as they are involved in corrupt practices. In this scenario, these interviewees believed that it should remain voluntary unless some institutional reforms are made.

"When you have regulation without the regulators with [the] capacity then it is very difficult to impose this kind of conditionality. At the end of the day, you must measure the impact. So, suppose if a company is to spend 2.5 million on CSR and that company while spending only half a million disclose it as 2.5 million, who is going to measure it. This will then open another door for corruption as officials can be bribed easily. This will also discourage those businesses which comply honestly as at the end of the day it adds with their cost. So, someone who is complying with dishonesty will have an edge over someone who is complying with honesty." (Project Manager, Local Environmental NGO).
The statement clearly raises the issues of accountability that arises from the institutional and political economy theory.

This is a very tricky situation as without mandatory reporting businesses may not take it seriously, but it could open spaces for innovative practices and/or responsible practices in a real sense. Mandatory reporting may result in tick-box compliance, but it could stifle innovation. Also because of weak institutions, businesses can easily find a way to go around the regulation without any substantive action. The key, therefore, lies in the institutional reforms that accompany these administrative reforms if they are to be fruitful (Belal et al. 2013). One of the interviewees nicely concluded this debate of mandatory vs. voluntary reporting in these words.

"I think keeping it voluntary is better for evolution, I think it's better to allow companies to evolve to a degree of open reporting but then at the end of the day for the sake of the public interest, if companies are not achieving the overall macro goals then, there is a need to introduce legislation." (Country Head, Foreign Professional Accounting Body).

As far as regulators are concerned, SECP wanted to make SR mandatory for all listed companies. In 2009, SECP issued a mandatory CSR General Order that stated listed companies to include monetary and descriptive disclosures of CSR activities in their directors' report. Further, based on stakeholder inputs and to promote CSR culture in the companies and to focus more on wider societal interests, SECP developed CSR voluntary guidelines in 2012. The focus of these guidelines was more on processes, committees, policy, goals and achievements, disclosure and reporting, and independent assurance of CSR performance (Mahmood et al. 2018). These guidelines were being proposed as a framework to facilitate sustainable growth, responsible business

\footnotetext{
${ }^{2}$ Environment Protection Department

${ }^{3}$ Monthly in this context is a bribe amount which is fixed per month.
} 
behaviour and corporate accountability (SECP 2012). There is evidence that mandatory regulative forces have significant effects on SR practices. Masud et al. 2018a, b, 2017 and Hossain et al. 2017 (Bangladesh); Gatti et al. 2018; Goel 2018 (India) and Bissoon 2018 (Mauritius) documents that specific regulation significantly influenced green and CSR disclosure practices in Bangladesh; India and Mauritius respectively. Moreover, Masud et al. 2018a, b and Bae et al. 2018 found that South Asian countries updated corporate governance and SR regulation explicitly and implicitly enhance social and environmental disclosure practice and the argument is also consistent with Mahmood et al. 2018; Ehsan et al. 2018; Yunis et al. 2018 and Iqbal et al. 2018 (Pakistan). Moreover, mandatory CSR regulation of India since 2013 significantly encourages SR implementation in the country (Gatti et al. 2018; Goel 2018).

\section{Guidelines and standards}

There is consensus that reporting on sustainability using international standards is best as:

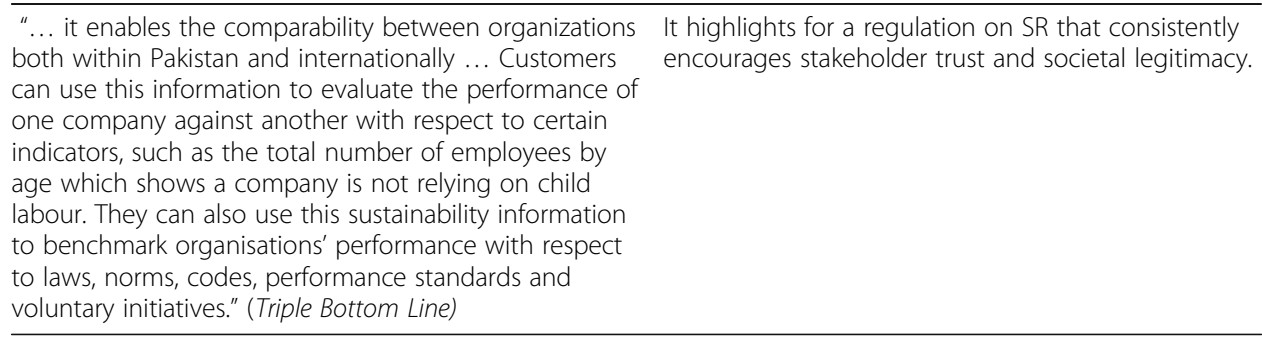

Using international standards was also perceived as important for increasing the confidence of capital markets and increasing the confidence of investors to attract foreign direct investment (Gatti et al. 2018; Yunis et al. 2018). For companies, SR can improve access to capital due to the trust that is established through such reporting between the investment community and the companies that present sustainability information.

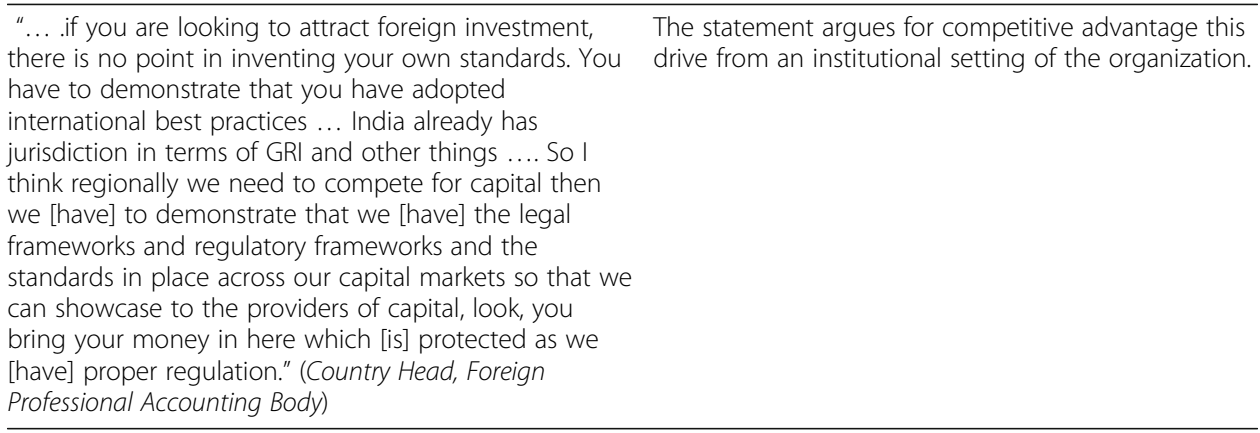

GRI is the main reporting standard used for the structure and process of standalone SR. As noted above, one of the main reasons for such an international standard is wider acceptance. However, as revealed by one of the interviewees, 
branding motives also play an important role in the adoption of GRI and for initiating the practice of SR.

"... So far the most important factor is branding ... GRI is becoming a brand .... Companies are taking these reports as branded products that add to their prestige, honour and

leadership position." (Partner, Management Consultancy Firm)
This is mostly relevant with stakeholder as well as institutional theory.

In the contrast, some interviewees feel that there is a need for a local standard or at least there is a need to tailor GRI to make it more relevant and understandable to a larger number of businesses. Also, to encourage SMEs, there is a need to develop a simple framework which is more relevant to them and which can be easily applied. There is a common perception that GRI is too technical and complex and there is a need for a consultant or a professional to understand its requirements and how it can be applied to the business.

\footnotetext{
"... we wanted to simplify GRI guidelines as for many of the companies GRI guidelines are very confusing ... Until you understand the purpose of indicators, reporting becomes a box-ticking exercise ......For our SMEs it is very difficult to get to the level of GRI application as they get confused, so for them, there is a need for simplification .... We need to simplify indicators and get rid of unnecessary indicators. There are hundreds of things which are important at [the] international level but [that] have little local significance." (Founder, First Enabler of CSR in Pakistan)
} $t$ argues for the simplification of the standard in the local business context that is driven from institutional coercive and mimetic

Simplification work is going on and some leading organizations are working on the development of simple, local and uniform guidelines. But lack of cooperation between different interest groups is hindering that process. One such effort is the responsible business guide (RBG 2010) which presents a toolkit for companies to implement and disclose sustainability practices. The argument denotes to the institutional theoretical liens and consistent with the finding of Masud et al. 2018a, b while they argue following GRI guidelines Bangladeshi Banking companies discloses credible information than non-GRI companies. Moreover, Gatti et al. 2018 also argue the same line of the conclusion of mandatory SR regulation in India. It is also evident that sound and standard SR regulation ensure institutional transparency by the coercive, mimetic and normative forces. Additionally, SR incurs accountability that reduces possible political cost and mitigates legitimacy threat.

\section{Perceived benefits of reporting}

There is a consensus among interviewees that SR is beneficial for ensuring the flow of long-term capital and raising competitiveness by increasing the transparency of the economic, social and environmental sustainability of the business. SR was perceived to drive shareholder value through (direct and/or indirect) cost and revenue advantages.

"... the process of producing reports enables businesses to internally identify operational inefficiencies, cut waste and save money for the company. For listed companies, this helps deliver shareholder value. Just as an external stakeholder can
This discussion can be explained by the multitheoretical discussion like; stakeholder, legitimacy, signaling, and political cost. 
Findings and discussion (Continued)

benchmark company performance from the information disclosed in these reports, this benchmarking information can also be helpful for the internal management of a company and driving improved performance." (Triple Bottom Line)

"... good companies report on their sustainability issues and set targets for improvements. For example, energy conservation, water consumption. Then they use different ways to reduce them and this leads to direct costing benefits." (Partner, Management Consultancy Firm)

"SR gives you an opportunity to share good work in an open and transparent way with your stakeholders (e.g. nearby community) so they should be aware of it and can give us a suggestion for improvements" (Manager HR and CSR, National Petroleum Company)

At the same time, several interviewees from the corporate sector mentioned that SR is a costly affair and very difficult to justify as there is no direct benefits and related regulation. This has been a major hindrance as, in the absence of any legal requirements; perceived benefits are more indirect and intangible. Also, these benefits are not well-understood.

"I think tangible [financial] benefits are unclear". (Manager HR and CSR, National Petroleum Company)

The Multi-theoretical discussion like; stakeholder, legitimacy, signaling, and political cost.

"Very few companies are realising this, that they have their own business benefits in this reporting. The whole process is learning-based. The general managerial attitude is that unless there is a direct financial benefit for something they do not understand the value." (Founder, First Enabler of CSR in Pakistan)

However, there are some large progressive organizations that believe that SR is beneficial in the long-run. For example, a corporate manager of one such progressive organization reflected on the benefits of SR.

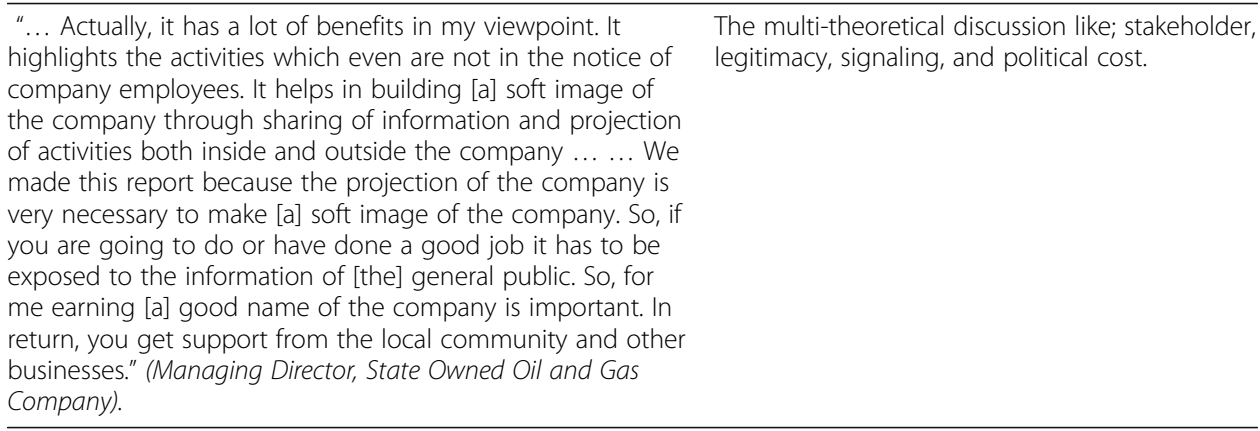

It seems SR can be used to mitigate social and stakeholders' pressures if the organisation finds perceived benefits of reporting. The discussion also highlight the common gap of Pakistani policy as well as business decision makers the importance and potentiality of the SR in the decision making process (Malik and Kanwal 2016; Sharif and Rashid 2014; Mahmood et al. 2018; Ehsan et al. 2018; Yunis et al. 2018; 
Iqbal et al. 2018). Therefore, it is emergence to find the mechanism of how to understand the explicit and implicit cost and benefits of SR to the management and stakeholders.

\section{Stakeholders' engagement/influence}

In theory, stakeholder engagement is described as the main mechanism of SR through which stakeholders can influence companies for better sustainability performance. In a country where there is a lack of sustainability awareness and interest, it is readily understood that the clear majority of stakeholders are either not interested in or are not in a position to influence companies. This is a big question mark on the importance of SR in this context and its ability to make any difference. Some interviewees, especially those involved in the practice, speak on these issues and explained how it is missing in the context of Pakistan.

"There is very little stakeholder engagement in SR. When we do [hold] stakeholder engagement sessions people ask questions about it (like what is this? and why you are doing this?). When we ask people about important issues especially the ones they want to be reported, they often say that report anything/everything. The concept of materiality which should be used to decide ... what to report is ignored in practice as stakeholders are unable to attach importance to different issues....... This is mainly due to lack of awareness and interest in [the] part of both [the] company and the stakeholders towards stakeholders' engagement. Apart from this in our society, we don't have a strong communication culture and we do have power distance which acts as [a] barrier for such engagement. But slowly awareness is increasing in the form of seminars, training, and voluntary guidelines." (Director, Consultancy Firm on CSR and Sustainability)

Zooming in at the corporate practice of stakeholder engagement, there are very few companies that mention the process of stakeholder engagement in their sustainability reports. Among the companies that did mention it, the method of engagement, selection of different stakeholders, and the level and seriousness of such an engagement differ from one company to another. Overall, the level of engagement was found to be no engagement at the worst and controlled engagement (stakeholder management) at the best. The following quotes reflect these issues:

Stakeholders' involvement is the main element in sustainability. We are at [a] very initial level in that. In foreign [countries] there are stakeholders' advisory councils but here we deliberately keep stakeholders out of the process as we want to have everything in our hand. The overall impression of companies is that we know better ....... Further, stakeholders are not taken seriously by the companies. Companies are reporting from their own perspective. (Partner, Management Consultancy Firm)

Meaningful stakeholder engagement depends on the way you do it. Our approach for stakeholder engagement was very professional. First, we did internal analysis and then we did external analysis. We engage with around 300 of the stakeholders (bankers, regulators, employees, contractors, suppliers, workers, community) and we had very interesting sessions ......The] community voice was there but it was a controlled voice just like the way NGOs did. They go with their agenda and then they do actions based on their agenda by asking them and taking their consent. (Founder, First Enabler of CSR in Pakistan)
The discussion mostly complies with the stakeholder and social legitimacy theoretical discussion. 
Some of the companies reporting of sustainability involved consultants for stakeholder engagement sessions. Very few companies disclosed the process of stakeholder engagement in their sustainability reports, indicating the number of stakeholders they engage with, their comments and mechanism for such engagement. Stakeholder engagement is the prime priority for accelerating SR because stakeholder creates internal and external forces that leads more disclosure. Moreover, to mitigate legitimacy gap disclosure practice is the pioneer tools of the management. Stakeholder engagement reduces information asymmetry and sends an honest signal to the market (Bae et al. 2018). Moreover, the most recent studies find an increasing pattern of stakeholders engagement in the Pakistani organisations (Khan et al. 2019; Mahmood et al. 2018; Ehsan et al. 2018; Yunis et al. 2018; Iqbal et al. 2018).

\section{Transparency and accountability}

Pakistan stands low in transparency and accountability at all levels (Yunis et al. 2018). At the government level, there is very little transparency and accountability because of many socio-economic and socio-political problems (Javeed and Lefen 2019; Yunis et al. 2018). There is a lack of systems that should be in place for ensuring transparency and accountability. For example, most of the government departments and public sector enterprises are keeping financial records based on a single-entry system. At the businesses level, there are also several businesses (mainly in the SME) that do not involve professional accountants and where the accounting system is very poor. In the absence of financial accountability, where there are strict regulation and benchmarks, how can companies be transparent and held accountable for their sustainability performance, especially when there is no legislation and no public demand? An interviewee describes the state of transparency in the current practice of SR as:

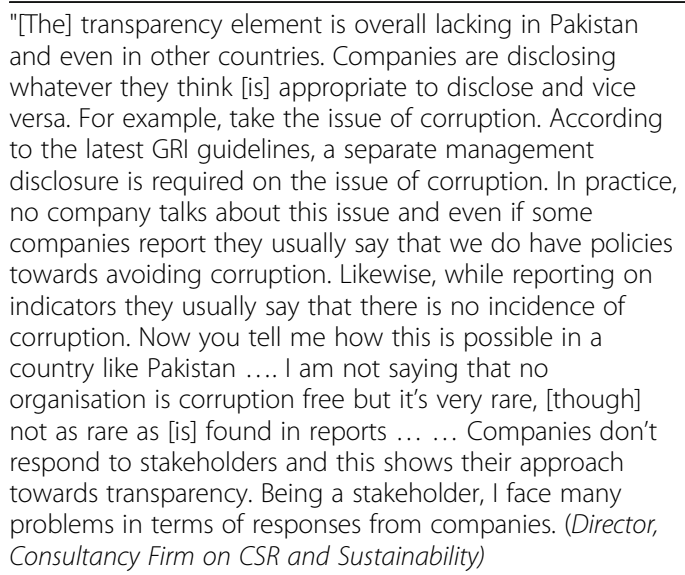

Whether transparency leads to accountability and whether SR results in making corporates accountable for their sustainability performance, there was a difference of opinion among practitioners. While corporate managers believe that SR makes them accountable by raising the transparency of their sustainability information, other social actors believe that the element of accountability is missing from the equation. 
Findings and discussion (Continued)

Publishing a report makes you accountable as every word stakeholder and signalling theory point of view.
you write can be challenged. (Manager Corporate
Communications and Public Affairs, Multinational Chemicals
Company)
When you publish [a] sustainability report, stakeholders
become more aware of what is wrong and what is right. So,
a person who is working on your environment, he sees
something which the company is not doing or according to
what is published it isn't doing. He becomes aware of that,
so he raises an issue. (Executive Corporate Communication
and CSR, National Fertilizers Company)
Large companies are varying [in] public opinion and the
bigger the company is the more sensitive they will be about
public opinion. By reporting on sustainability their
accountability is increased as they expose themselves and
face the risk of their reputation. But that accountability is not
like financial accountability as in financial accounting there
are [a] number of regulatory frameworks which makes
accountability much tighter so in SR there are no such
regulations (Country Head, Foreign Environmental NGO).

However, according to one of the interviewees, the accountability element can be present if companies report objectively in the form of quantified targets. Currently, there are very few companies which are reporting against quantified targets.

$\begin{aligned} & \text { "When you are required to report publicly on economic, } \\ & \text { social and environmental [issues] then it becomes an }\end{aligned}$
obligation for you. In Pakistan, most of the reports are not
giving targets. If given they are very vague. Unless you don't
quantify the targets, how [can] you be accountable for that?
When you quantify that you will decrease this by this much
percentage and you publicly disclose on that then you are
accountable. But we are not on this track so far." (Manager
Corporate Communications and Public Affairs, Multinational
Chemicals Company)

Disclosure practices are one of the well-recognised and popular ways to be accountable to society and stakeholders. Sound SR practices reduce political pressures and increase accountability to society. SR initiatives circulate management willingness to the society that increases the perceived benefit of the business. Further, transparency and accountability reduce political cost and increase reputation to the society that reduces the legitimate threat from negative events. Moreover, transparency sends an honest signal to the market and diverse stakeholders. Shirodkar et al. 2016 find MNC's in India invested in CSR to reduce potical pressure and legitimate with the local people.

A brief summary of the above mentioned SR actors' and theoretical connection is given below (Table 2):

\section{Conclusions}

Currently, sustainability reporting is voluntary. Regulators are trying to make it mandatory. Mandatory SR is considered as the ultimate solution for raising transparency and accountability of the companies towards sustainability performance (Gatti et al. 2018; Goel 2018; Bissoon 2018). However, there is some resistance by businesses as they are concerned about increased compliance and the possibility of 
Table 2 A Snapshot of SR Actors' in Pakistan and Theory Relevance

\begin{tabular}{|c|c|c|}
\hline SR actors' & Causes & Theory relevance of SR \\
\hline $\begin{array}{l}\text { Sustainability } \\
\text { Awareness }\end{array}$ & $\begin{array}{l}\text { Awareness raises more and more questions } \\
\text { that ultimately comply with the regulation. }\end{array}$ & $\begin{array}{l}\text { Stakeholder's management and institutional } \\
\text { isomorphism. }\end{array}$ \\
\hline $\begin{array}{l}\text { Sustainability } \\
\text { Interest }\end{array}$ & $\begin{array}{l}\text { Sustainability interest lies in explicit and } \\
\text { implicit CSR. Political connectedness also } \\
\text { incurs the cost and finally intermediate with } \\
\text { regulation and legitimacy. }\end{array}$ & Political cost and social legitimacy. \\
\hline $\begin{array}{l}\text { Incentive and } \\
\text { Award }\end{array}$ & $\begin{array}{l}\text { SR performance seeks competitive advantages. } \\
\text { Socially responsible firms are willing to serve } \\
\text { the society in response to recognition. It } \\
\text { reduces the legitimacy gap and enhances } \\
\text { visibility. }\end{array}$ & Signalling and legitimacy. \\
\hline $\begin{array}{l}\text { Foreign } \\
\text { Influence }\end{array}$ & $\begin{array}{l}\text { The foreign company follows norms and } \\
\text { standard of the home country and very much } \\
\text { concern with legitimacy with society. Local } \\
\text { firms face coercive and mimetic pressures that } \\
\text { help is the institutionalization process. }\end{array}$ & Institutional and legitimacy. \\
\hline $\begin{array}{l}\text { Professional } \\
\text { Associations }\end{array}$ & $\begin{array}{l}\text { Professionalism refers to normative values in } \\
\text { the specific field. A professional person can } \\
\text { play a significant role in the formation of } \\
\text { standard, rules, and certification of the CSR } \\
\text { performance that will create competitive } \\
\text { advantages. }\end{array}$ & $\begin{array}{l}\text { This argument explains the concept of } \\
\text { institutional theory. }\end{array}$ \\
\hline $\begin{array}{l}\text { Regulation } \\
\text { and } \\
\text { Enforcement }\end{array}$ & $\begin{array}{l}\text { The performance and rationality of SR broadly } \\
\text { depend on regulation and standard. Minimum } \\
\text { regulation is better than no regulation. The } \\
\text { performance of regulation also depends on } \\
\text { enforcement. Lack of awareness, interest, } \\
\text { accountability and low control of corruption } \\
\text { characteristics drives a mandatory SR } \\
\text { regulation. }\end{array}$ & $\begin{array}{l}\text { The concept of institutional theory explicitly } \\
\text { and implicitly discuss regulation and standard. } \\
\text { On the other hand, lack of enforcement arises } \\
\text { many types of the political cost. }\end{array}$ \\
\hline $\begin{array}{l}\text { Guidelines } \\
\text { and Standard }\end{array}$ & $\begin{array}{l}\text { Standard and guidelines involve transparency } \\
\text { and accountability of the organisation that } \\
\text { creates competitive advantages, visibility and } \\
\text { growth of the organisation. For example, most } \\
\text { of the fortune } 500 \text { firms comply with SRI } \\
\text { standard. }\end{array}$ & $\begin{array}{l}\text { Institutional isomorphism is the process } \\
\text { whereas, firms can mitigate different types of } \\
\text { internal and external pressures by complying } \\
\text { SR standard. }\end{array}$ \\
\hline $\begin{array}{l}\text { Perceived } \\
\text { Benefits of } \\
\text { Reporting }\end{array}$ & $\begin{array}{l}\text { SR has a significant impact on the } \\
\text { organisations' performance. It reduces } \\
\text { information asymmetry between management } \\
\text { and agents. Information disclosure enhances } \\
\text { transparency and accountability that reduces } \\
\text { the societal and political threat of the firms. }\end{array}$ & $\begin{array}{l}\text { SR benefits can be used a multi-stakeholder } \\
\text { theoretical framework like; stakeholder, legitim- } \\
\text { acy, institutional, signalling and political cost. } \\
\text { The prior study used all of these theories in the } \\
\text { discussion of SR effectiveness. }\end{array}$ \\
\hline $\begin{array}{l}\text { Stakeholders' } \\
\text { Engagement }\end{array}$ & $\begin{array}{l}\text { One of the important roles of SR is to engage } \\
\text { diverse stakeholder in the decision making } \\
\text { process of the firms. Mapping stakeholder and } \\
\text { mitigating agency conflicts are critically } \\
\text { evaluated by CSR initiatives. }\end{array}$ & $\begin{array}{l}\text { Prior study commonly used stakeholder and } \\
\text { legitimacy theory in the discussion of } \\
\text { stakeholder engagement of SR. }\end{array}$ \\
\hline Transparency & $\begin{array}{l}\text { SR goal is to make the firm more transparent } \\
\text { and accountable to the diverse stakeholders'. } \\
\text { Firms overall performance, engagement, and } \\
\text { opportunistic behaviour depends on how } \\
\text { much it is transparent and how information is } \\
\text { available. Transparent firms quickly send } \\
\text { obedient signals to the market and } \\
\text { stakeholders. }\end{array}$ & $\begin{array}{l}\text { Most of the SR theoretical framework is driven } \\
\text { for increasing transparency and accountability } \\
\text { of the firms that influences SR strategy. } \\
\text { Therefore, stakeholder, legitimacy and } \\
\text { signalling theory may best fit with the } \\
\text { discussion. }\end{array}$ \\
\hline
\end{tabular}

increased corruption. GRI has been adopted as the main reporting standards for structure and process of standalone SR. The main logic of using GRI is to increase investor confidence by adopting international standards. However, there are some serious concerns about the understanding and application of GRI to the local context 
of Pakistan. There is a common understanding that SR brings intangible benefits. However, appreciation and understanding of tangible benefits are unclear. This was considered as another hindrance towards adopting SR as without any direct benefits it is difficult to justify the costs. Only large organisations are doing it as they can afford and wait for the long-term benefits. Stakeholders' engagement, which is considered as the main mechanism for SR is extremely lacking in Pakistan because of both the lack of sustainability awareness and interest. Most of the companies did not mention the stakeholder engagement process in sustainability reports. The method of engagement, selection of different stakeholders, the level and seriousness of such engagement differ from one company to another. There are serious questions about transparency and accountability of sustainability information presented in the sustainability reports. Currently, there are very few companies which are presenting their targets in an objective manner.

According to the stakeholder's theory, stakeholder's engagement is the prime issues in the SR development. It seems in the recent study that Pakistani business management is trying to engage different stakeholder because of social and market pressures as well as stakeholder's confidence signal to the organisation. On the other hand, seeking social legitimacy different forces can play a vital role but the present situation defines a lack of interest, motivations, and benefits discourage management for SR practices. Moreover, the study finds no coercive and normative pressure on SR while, there is a little mimetic force because of voluntary guidelines. Since 2012 voluntary CSR guidelines and updated corporate governance regulations like to believe us imperative forces on SR initiatives to the institutional environment. It is evident that Pakistani business management is reluctant about political forces regarding social and environmental investment because of political connectedness management that reduce SR practices. The study profoundly finds fewer pressures from political government, diverse stakeholders and, society; therefore, SR practices are still lagging in the country. It is also finding that management does not consider SR as a strategic tool rather than "wishes" of personal desire or interests. Our all theoretical discussion reveals scatter influences in the Pakistani business environment. Furthermore, we document that many actors/drivers believe the SR importance, and demanding for institutional changes that will make SR as an emerging issue in sustainable business management. Further, we consider stakeholder's pressures (NGO; environmental action groups; international community), normative regulations and emerging market signals will positively impact on SR revolution in Pakistan.

This paper concludes that, like other developing countries, the practice of sustainability reporting is largely driven by external forces. Foreign buyers, international professional associations and standard setting organizations are playing a pivotal role in the emergence and development of sustainability reporting. Sustainability reporting awards also played an important role as they provide the normative basis and intangible benefits for reporting. Despite these external forces driving the emergence and development of SR in Pakistan, the structural and cultural conditions that exist in the societal context of Pakistan significantly impact the disclosure practices and organizational rationales for SR. In particular, weak government structures, lack of awareness and interest in sustainability matters, lack of regulation, lack of enforcement capabilities, lack of a political will has been identified 
as the main barriers of SR. Despite the distinct sustainability challenges in Pakistan, understanding of these challenges and the contribution of SR is very poor. The prevailing structural and cultural conditions resulted in a lack of expectations and pressures from local stakeholders (Islam and Deegan 2008; Belal et al. 2015). These conditions act as constraints and provide an explanation for lack of reporting. In the absence of these internal conditions and pressures, a major motivation for SR is externally driven and rests on the business case. In this context, this paper agrees with Belal and Roberts 2010; Belal and Owen 2015; Goel 2018; Masud et al. 2018a, b; Shirodkar et al. 2016 that unless institutional arrangements are improved in these countries, SR will fail to deliver expectations of transparency and accountability. Also, mandatory reporting may lead to unintended consequences.

Overall, this paper attempts to improve our understanding of why sustainability reporting is, or is not, evolving and emerging in emerging and developing economies (Ahmad 2010; Belal 2008; Belal and Cooper 2011; Mahadeo et al. 2011; Momin and Parker 2013). Overall, this paper contributes to the literature of sustainability reporting in emerging and developing economies. Unlike previous studies that focus on the perception of either managerial or non-managerial stakeholders, this paper studied the perceptions of both types of stakeholders and presented a more balanced view of the major players in Pakistan. Therefore, the study largely contributed to the SR literature deploying five sets of theoretical discussion specially, in an emerging economy. Pakistan, a developing as well as less control of corruption country political and signalling theory posits the emergence of SR in the business management. The study has highly managerial implications in Pakistani business management because of the actor's/drivers we identified are very crucial for the SR development and implementation. Moreover, policy makers can consider different drivers of the SR, further development of regulations, guidelines as well as enhancing the motivations and interests. The study vividly focuses on the importance of stakeholder's engagement, the role of political motivations, the pathway of encouraging management and the rule of professional bodies to be ambitious on mainstream SR practices. Therefore, we like to conclude that Pakistani policy makers and business management should work together to produce a holistic mandatory SR regulation for a transparent and accountable business environment to achieve sustainable development goals.

Abbreviations

ACCA: Association of Chartered Certified Accountants; CCl: Chamber of Commerce and Industry; CPD: Continuing Professional Development; CSR: Corporate Social Responsibility; CSRCP: Corporate Social Responsibility Center of Pakistan; EPD: Environmental Protection Department; GRI: Global Reporting Initiative; ICAP: Institute of Chartered Accountants of Pakistan; ICMAP: Institute of Cost and Management Accountants of Pakistan; IFAC: International Federation of Accountants; IMF: International Monetary Fund; MNC: Multinational Companies; PCl: Pakistan Compliance Initiative; PERA: Pakistan Environmental Reporting Awards; RBI: Responsible Business Initiative; SR: Sustainability reporting; UNGC: United Nations Global Compact; WWF: Word Wildlife Fund

\section{Acknowledgements}

Not applicable.

\section{Authors' contributions}

ZM carried out the empirical studies, the literature review, and drafted the manuscript. RK helped with the background, data analysis, and discussion. AKM updated the literature review, added theories and improved the theoretical discussion of the paper and revised the paper according to the reviewer's comments, communicate with the editor. All authors read and approved the final manuscript.

Funding

There is no funding applicable to this project. 
Availability of data and materials

Not applicable.

\section{Competing interests}

The authors declare that they have no competing interests.

\section{Author details}

${ }^{1}$ Department of Commerce, BZ University, Multan, Pakistan. ${ }^{2}$ Department of Sustainability Management, Inha University, Incheon 22212, South Korea. ${ }^{3}$ Department of Business Administration, Noakhali Science and Technology University, Noakhali 3814, Bangladesh.

Received: 19 January 2019 Accepted: 9 July 2019

Published online: 01 August 2019

\section{References}

Abayo AG, Adams CA, Roberts CB (1993) Measuring the quality of corporate disclosure in less developed countries: the case of Tanzania. J Int Account Audit Tax 2(2):145-158

Adams CA, Larrinaga-Gonzalez C (2007) Engaging with organisations in pursuit of improved sustainability accounting and performance. Accounting, Auditing \& Accountability Journal 20(3): 333-355.

Ahmad SJ (2010) From principles to practice: exploring corporate social responsibility in Pakistan

Ali W, Frynas JG, Mahmood Z (2017) Determinants of corporate social responsibility (CSR) disclosure in developed and developing countries: a literature review. Corp Soc Respon Environ Manag. https://doi.org/10.1002/csr.1410

Amran A, Haniffa R (2011) Evidence in development of sustainability reporting: a case of a developing country. Bus Strateg Environ 20(3):141-156

Ashforth BE, Gibbs BW (1990) The double-edge of organizational legitimation. Organ Sci 1(2):177-194

Bae S, Masud MAK, Kim J (2018) A cross-country investigation of corporate governance and corporate sustainability disclosure: a signaling theory perspective. Sustainability 10(8):2611. https://doi.org/10.3390/su10082611

Balkhi K (2010) Pakistan. In: Visser W, Tolhurst N (eds) The world guide to CSR: A country-by-country analysis of corporate sustainability and responsibility. Greenleaf Publishing, UK

Baral N, Pokharel MP (2017) How sustainability is reflected in the S\&P 500 companies' strategic documents. Organ Environ 30(2):122-141. https://doi.org/10.1177/1086026616645381

Belal A, Owen DL (2015) The rise and fall of stand-alone social reporting in a multinational subsidiary in Bangladesh. Account Audit Account J 28. https://doi.org/10.1108/AAAJ-08-2013-1443

Belal A, Spence C, Carter C, Zhu L (2017) The Big 4 in Bangladesh: caught between the global and the local. Account Audit Account J 30(1):145-163. https://doi.org/10.1108/AAAJ-10-2014-1840

Belal AR (2000) Environmental reporting in developing countries: empirical evidence from Bangladesh. Eco-Manag Audit 7(3):114-121

Belal AR (2001) A study of corporate social disclosures in Bangladesh. Manag Audit J 16(5):274-289

Belal AR (2008) Corporate social responsibility reporting in developing countries: the case of Bangladesh. Ashgate Pub Co, UK

Belal AR, Cooper S (2011) The absence of corporate social responsibility reporting in Bangladesh. Crit Perspect Account 22(7):654-667

Belal AR, Cooper SM, Khan NA (2015) Corporate environmental responsibility and accountability: what chance in vulnerable Bangladesh? Crit Perspect Account 33:44-58. https://doi.org/10.1016/j.cpa.2015.01.005

Belal AR, Cooper SM, Roberts RW (2013) Vulnerable and exploitable: the need for organisational accountability and transparency in emerging and less developed economies. In: Paper presented at the Accounting Forum

Belal AR, Momin M (2009) Corporate social reporting (CSR) in emerging economies: a review and future direction. Res Account Emerg Econ 9:119-143

Belal AR, Owen DL (2007) The views of corporate managers on the current state of, and future prospects for, social reporting in Bangladesh: an engagement-based study. Account Audit Account J 20(3):472-494

Belal AR, Roberts RW (2010) Stakeholders' perceptions of corporate social reporting in Bangladesh. J Bus Ethics 97(2):311-324

Bissoon O (2018) Corporate social responsibility in Mauritius: an analysis of annual reports of multinational hotel groups. Asian J Sustain Soc Responsib 3(1):2. https://doi.org/10.1186/s41180-017-0017-4

Comyns B (2016) Determinants of GHG reporting: an analysis of global oil and gas companies. J Bus Ethics 136(2):349-369. https://doi.org/10.1007/s10551-014-2517-9

Connelly BL, Certo ST, Ireland RD, Reutzel CR (2011) Signaling theory: a review and assessment. J Manag 37(1):39-67. https://doi.org/10.1177/0149206310388419

Correa C, Larrinaga C (2015) Engagement research in social and environmental accounting. Sustain Account Manage Policy J 6(1):5-28

Crane A, McWilliams A, Matten D, Moon J, Siegel DS (2008) The Oxford handbook of corporate social responsibility. Oxford University Press, UK

de Villiers C, Naiker V, van Staden CJ (2011) The effect of board characteristics on firm environmental performance. J Manag 37(6):1636-1663. https://doi.org/10.1177/0149206311411506

De Villiers C, Van Staden CJ (2006) Can less environmental disclosure have a legitimising effect? Evidence from Africa. Acc Organ Soc 31(8):763-781

Deloitte (2012). Sustainability reporting in Pakistan. Retrieved from https://www2.deloitte.com/content/dam/Deloitte/pk/ Documents/governance-risk-compliance/survey-report-Delotte-Pakistan-noexp.pdf.

DiMaggio P, Powell WW (1983) The iron cage revisited: institutional isomorphism and collective rationality in organiza- tional fields. Am Sociol Rev 48(2):147-160

Dissanayake D, Tilt C, Xydias-Lobo M (2016) Sustainability reporting by publicly listed companies in Sri Lanka. J Clean Prod 129:169-182. https://doi.org/10.1016/j.jclepro.2016.04.086

Dowling J, Pfeffer J (1975) Organizational legitimacy: social values and organizational behavior. Pac Sociol Rev 18(1):122-136 
Ehsan S, Nazir MS, Nurunnabi M, Khan QR, Tahir S, Ahmed I (2018) A multimethod approach to assess and measure corporate social responsibility disclosure and practices in a developing economy. Sustainability (Switzerland) 10(8). https://doi.org/10.3390/su10082955

Eweje G (2014) Corporate social responsibility and sustainability: emerging trends in developing economies, vol 8. Emerald Group Publishing, UK

Ezhilarasi G, Kabra KC (2017) The Impact of Corporate Governance Attributes on Environmental Disclosures: Evidence from India. Indian J Corp Governance 10(1):24-43

Freeman ER (1984) Strategic management: a stakholder approach. Pitman, Boston

Fayyaz A, Lund-Thomsen P, Lindgreen A (2015) Industrial clusters and CSR in developing countries: the role of international donor funding. J Bus Ethics: 1-19. https://doi.org/10.1007/s10551-015-2940-6.

Freeman R, Harrison J, Wicks A, Parmar B, Colle S (2010) Stakeholder theory: the state of the art. Cambridge University Press, New York

Gatti L, Vishwanath B, Seele P, Cottier B (2018) Are we moving beyond voluntary CSR? Exploring theoretical and managerial implications of mandatory CSR resulting from the new Indian companies act. J Bus Ethics. https:/doi.org/10.1007/s10551-018-3783-8

Goel P (2018) Implications of corporate governance on financial performance: an analytical review of governance and social reporting reforms in India. Asian J Sustain Soc Responsib 3(1):4. https://doi.org/10.1186/s41180-018-0020-4

Gray RH, Owen D, Adams C (2009) Some theories for social accounting?: a review essay and a tentative pedagogic categorisation of theorisations around social accounting. In: Sustainability, environmental performance and disclosures. Emerald Group, UK, pp 1-54

Guardian. (2011). Sustainability reports: who is reading the things? Retrieved from http://www.guardian.co.uk/sustainablebusiness/blog/sustainability-cSr-reporting

Hoque A, Clarke C, Huang L (2016) Lack of Stakeholder Influence on Pollution Prevention. Organization \& Environment 29(3): 367-385. https://doi.org/10.1177/1086026615623057

Hoque N, Rahman ARA, Molla Rl, Noman AHM, Bhuiyan MZH (2018) Is corporate social responsibility pursuing pristine business goals for sustainable development? Corp Soc Responsib Environ Manag 25(6):1130-1142. https://doi.org/10.1002/csr.1527

Hossain MM, Momin M, Rowe A, Quaddus M (2017) Corporate social and environmental reporting practices: a case of listed companies in Bangladesh. Sustain Account Manage Policy J 8(2). https://doi.org/10.1108/SAMPJ-04-2015-0027

Hu M, Loh L (2018) Board governance and sustainability disclosure: a cross-sectional study of Singapore-listed companies. Sustainability (Switzerland) 10(7):1-14. https://doi.org/10.3390/su10072578

Husted BW, de Sousa-Filho JM (2018) Board structure and environmental, social, and governance disclosure in Latin America. J Bus Res (January). https://doi.org/10.1016/j.jbusres.2018.01.017

Imam S (2000) Corporate social performance reporting in Bangladesh. Manag Audit J 15(3):133-142

IMF (2012) The Rising Resilience of Emerging Market and Developing Economies. https://www.imf.org/external/pubs/ft/wp/2 012/wp12300.pdf. Accessed 16 Jul 2019

Iqbal S, Farid T, Jianhong M, Khattak A, Nurunnabi M (2018) The impact of authentic leadership on organizational citizenship Behaviours and the mediating role of corporate social responsibility in the banking sector of Pakistan. Sustainability 10(7): 2170. https://doi.org/10.3390/su10072170

Islam MA (2010) Social and environmental accounting research: major contributions and future directions for developing countries. J Asia Pac Cent Environ Account 16(2):27-43

Islam MA, Deegan C (2008) Motivations for an organisation within a developing country to report social responsibility information: evidence from Bangladesh. Account Audit Account J 21(6):850-874

Javeed S, Lefen L (2019) An analysis of corporate social responsibility and firm performance with moderating effects of CEO power and ownership structure: a case study of the manufacturing sector of Pakistan. Sustainability:11-248. https://doi. org/10.3390/su11010248

Khan I, Khan I, Saeed B (2019) Does board diversity affect quality of corporate social responsibility disclosure? Evidence from Pakistan. Corp Soc Resp Env Ma 2019:1-11. https://doi.org/10.1002/csr.1753

KPMG (Producer) (2013). The KPMG survey of corporate social responsibility reporting 2013. Retrieved from https:// blogmaterialityreporting.files.wordpress.com/2013/12/kpmg-corporate-responsibility-reporting-survey-2013.pdf. Accessed 16 July 2019.

Lone E, Ali A, Khan I (2016) Corporate governance and corporate social responsibility disclosure: evidence from Pakistan. Corp Gov 16(5):785-797. https://doi.org/10.1108/CG-05-2016-0100

Mahadeo JD, Oogarah-Hanuman V, Soobaroyen T (2011) Changes in social and environmental reporting practices in an emerging economy (2004-2007): exploring the relevance of stakeholder and legitimacy theories. In: Paper presented at the Accounting Forum

Mahmood Z, Kouser R, Ali W, Ahmad Z, Salman T (2018) Does corporate governance affect sustainability disclosure? A mixed methods study. Sustainability 10(1):207. https://doi.org/10.3390/su10010207

Majeed S, Aziz T, Saleem S (2015) The effect of corporate governance elements on corporate social responsibility (CSR) disclosure: an empirical evidence from listed companies at KSE Pakistan. Int J Financ Stud 3(4):530-556. https://doi.org/10.3390/ijfs3040530

Malik MS, Kanwal L (2016) Impact of corporate social responsibility disclosure on financial performance: case study of listed pharmaceutical firms of Pakistan. J Bus Ethics:1-10. https://doi.org/10.1007/s10551-016-3134-6

Masud MAK, Bae S, Kim J (2017) Analysis of environmental accounting and reporting practices of listed banking companies in Bangladesh. Sustainability 9(10):1717. https://doi.org/10.3390/su9101717

Masud MAK, Hossain M, Kim J (2018a) Is green regulation effective or a failure: comparative analysis between Bangladesh Bank (BB) green guidelines and global reporting initiative guidelines. Sustainability 10(4):1267. https://doi.org/10.3390/su1 0041267

Masud MAK, Hossain MS (2012) Corporate social responsibility reporting practices in Bangladesh: a study of selected private commercial banks. IOSR J Bus Manag 6(2):42-47. https://doi.org/10.9790/487X-0624247.

Masud MAK, Nurunnabi M, Bae SM (2018b) The effects of corporate governance on environmental sustainability reporting: empirical evidence from south Asian countries. Asian J Sustain Soc Responsib 3(1):3. https://doi. org/10.1186/s41180-018-0019-x 
Matten D, Moon J (2008) "Implicit" and "explicit" CSR: a conceptual framework for a comparative understanding of corporate social responsibility. Acad Manage Rev 33(2):404-424

Meyer JW, Rowan B (1977) Institutionalized organizations: formal structure as myth and ceremony. Am J Sociol 83(2):340

Momin MA (2013) Social and environmental NGOs' perceptions of corporate social disclosures: the case of Bangladesh. In: Paper presented at the Accounting Forum

Momin MA, Parker LD (2013) Motivations for corporate social responsibility reporting by MNC subsidiaries in an emerging country: the case of Bangladesh. Br Account Rev 45(3):215-228. https://doi.org/10.1016/j.bar.2013.06.007

Muttakin MB, Mihret DG, Khan A (2018) Corporate political connection and corporate social responsibility disclosures. Account Audit Account J 31(2):725-744. https://doi.org/10.1108/AAAJ-06-2015-2078

Naeem MA, Welford R (2009) A comparative study of corporate social responsibility in Bangladesh and Pakistan. Corp Soc Responsib Environ Manag 16(2):108-122. https://doi.org/10.1002/csr.185

Nazir MS (2010) Corporate social disclosure in Pakistan: a case study of fertilizers industry. J Commer 2(1):1-11

Nazish S (2014) Regulating corporate social responsibility in Pakistan. Triple Bottom Line Magazine. http://www.tbl.com.pk/ regulating-corporate-social-responsibility-in-pakistan. Accessed 16 July 2019.

Nurunnabi M (2016) Who cares about climate change reporting in developing countries? The market response to, and corporate accountability for, climate change in Bangladesh. Environ Dev Sustain 18(1):157-186. https://doi. org/10.1007/s10668-015-9632-3

O'Dwyer B, Unerman J, Bradley J (2005) Perceptions on the emergence and future development of corporate social disclosure in Ireland: engaging the voices of non-governmental organisations. Account Audit Account J 18(1):14-43

Patel T, Rayner S (2012) A transactional culture analysis of corporate sustainability reporting practices: six examples from India. Bus Soc 54(3):283-321. https://doi.org/10.1177/0007650312445132

Patten DM (2014) Environmental disclosure as legitimation: is it in the public interest? In: Mintz S (ed) Accounting for the public interest. Springer, Amsterdam, pp 201-215

Perrault E, Clark C (2016) Environmental shareholder activism: considering status and reputation in firm responsiveness organization. Organ Environ 29(2):194-211. https://doi.org/10.1177/1086026615571939

RBG (2010). Responsible business guide: a toolkit for winning companies. Retrieved from https:/www.yumpu.com/en/ document/read/30594918/responsible-business-guide-a-toolkit-for-winning-companies.

Richardson AJ (1985) Symbolic and substantive legitimation in professional practice. Can J Sociol 10(2):139-152

Sanchez-Triana E, Biller D, Nabi I, Ortolano L, Dezfuli G, Afzal J, Enriquez S (2014) Revitalizing industrial growth in Pakistan: trade, infrastructure, and environmental performance. World Bank Publications, Washington

Sawani Y, Zain MM, Darus F (2010) Preliminary insights on sustainability reporting and assurance practices in Malaysia. Soc Responsib J 6(4):627-645

SECP. (2012). SECP gives nod to CSR guidelines

Shamil MM, Shaikh JM, Ho PL, Krishnan A (2014) The influence of board characteristics on sustainability reporting empirical evidence from Sri Lankan firms. Asian Rev Account 22(2):78-97. https://doi.org/10.1108/ARA-09-2013-0060

Sharif M, Rashid K (2014) Corporate governance and corporate social responsibility (CSR) reporting: an empirical evidence from commercial banks (CB) of Pakistan. Qual Quant 48(5):2501-2521. https://doi.org/10.1007/s11135-013-9903-8

Shirodkar V, Beddewela E, Richter UH (2016) Firm-level determinants of political CSR in emerging economies: evidence from India. J Bus Ethics:1-16. https://doi.org/10.1007/s10551-016-3022-0

Suchman MC (1995) Managing legitimacy: strategic and institutional approaches. Acad Manag Rev 20:571-610

Taj SA (2016) Application of signaling theory in management research: addressing major gaps in theory. Eur Manag J 34(4): 338-348. https://doi.org/10.1016/j.emj.2016.02.001

Uddin S, Siddiqui J, Islam MA (2016) Corporate social responsibility disclosures, traditionalism and politics: a story from a traditional setting. J Bus Ethics:1-20. https://doi.org/10.1007/s10551-016-3214-7

Visser W (2008) Corporate social responsibility in developing countries. In: The Oxford handbook of corporate social responsibility, pp 473-479

Watts RL, Zimmermann JL (1978) Towards a positive theory of the determination of accounting standards. Account Rev 53(1):112-134

Yadava RN, Sinha B (2016) Scoring sustainability reports using GRI 2011 guidelines for assessing environmental, economic, and social dimensions of leading public and private Indian companies. J Bus Ethics 138(3):549-558. https://doi.org/10.1 007/s10551-015-2597-1

Yunis MS, Jamali D, Hashim H (2018) Corporate social responsibility of foreign multinationals in a developing country context: insights from Pakistan. Sustainability (Switzerland) 10(10):11-15. https://doi.org/10.3390/su10103511

\section{Publisher's Note}

Springer Nature remains neutral with regard to jurisdictional claims in published maps and institutional affiliations. 